\title{
Field Notes
}

This issue's field notes will feature some past events and some future events. We hope the information is useful to all. Please feel free to spread it around.

1. ANNOUNCEMENT! The Journal of Russian American Studies (JRAS) is thrilled to announce that during the calendar year 2018, our website had more than 4,000 downloads of material. Those are downloads- not simply visits. This is a healthy rate of downloads for a journal of our age and interest group.

We are thankful for our readers, our contributors, and our editorial board. We are especially thankful for the support from the University of Kansas, most especially Marianne Reed and Pam LeRow, for their assistance in formatting and posting each issue.

2. The Russian State University for the Humanities and the Institute of World History at the Russian Academy of Sciences sponsored a conference in Moscow called "Turning Points in Ending the Cold War from Western and Eastern Perspectives, 1989-2019” on March 26-27, 2019. The pdf of the conference program is here.

See Cold War Program at: https://doi.org/10.17161/jras.v3i1.9796

3. Held on April 3, 2019 at the Kennan Institute in Washington, DC 


\section{$\underline{\text { Soviet and American Correspondence During the Cold War }}$}

This event is co-sponsored by the

Cold War International History Project.

Scholars have long assumed that there was little contact between Soviet and American civilians during the Truman-Stalin era, a time more associated with the dawn of the Cold War, McCarthyism in America, and the anti-western Zhdanovshchina in the Soviet Union. And yet, during this tumultuous time, American and Soviet women were in regular, intimate contact. Between 1944 and 1955, they exchanged over 500 letters, attempting to safeguard peace and advance mutual understanding by becoming pen-pals. Alexis Peri will present her research on how individual women confronted the complexities of ideology and policy through these letters, and how they negotiated personal, political, national, and international issues even as they became embroiled in Cold War politics.

\section{Speaker}

Alexis Peri, Assistant Professor, Boston University

\section{Discussant}

Christine Worobec, Professor Emerita, Northern Illinois University

4. The Wisconsin Historical Society in Madison is well-known for having a collection of personal papers related to folks who have RussianAmerican connections. An recent MA graduate from REECAS of the University of Wisconsin at Madison, Nicholas Seay, has been working with this material in a new way. The link below tells of what he has been doing.

https://creeca.wisc.edu/2019/03/the-wisconsin-russia-connection-more-thanjust-cold-winters/

5. The $51^{\text {st }}$ Annual Convention of the Association for Slavic, East European and Eurasian Studies (ASEEES) will meet in San Francisco in November 2019. There are several panels and roundtables that have been accepted to the program that are related to Russian-American studies. We have listed them here. The specific days and times have not been determined. See aseees.org for a program later in the summer.

\section{A. "Cold War Citizen Diplomacy"}

Discussant: Lyubov Ginzburg, Independent Scholar

Chair: Jennifer Hudson, U of Texas at Dallas

The Belief in Soviet-American Musical Encounters During the Cold War Meri Herrala, U of Helsinki (Finland);

Official, Professional, and Personal: Finnish-Soviet Artistic Networks in Context Simo Mikkonen, U of Jyväskylä (Finland); 
Global Citizens Defy Star Wars: How Spacebridges Promoted Star Peace Jennifer Hudson, U of Texas at Dallas;

B. "Revolution from Abroad and Internal Dissension: Émigré Anti-Communism and the Cold War"

Chair: Jennifer Hudson, U of Texas at Dallas

Discussant: Laurie Manchester, Arizona State U

Soviet Emigres and Old Russian Socialists during the Cold War: Hopes and Disappointments

Alexey Antoshin, Ural Federal U (Russia);

Judgment in Moscow? Returning Dissenters and the Struggle for Political

Authority in Moscow and Kiev, 1987-1991.

Manfred Zeller, Bremen U;

Emigre Anti-Communism meets American Philanthropy: The Ford Foundation's

East European Fund, 1950-1955

Benjamin Tromly, U of Puget Sound

C. "Religious dimension of Russian-American imagology: from the Tsarist Empire to Putin's Russia"

Chair: Lee Farrow, Auburn U at Montgomery

Discussant: William Whisenhunt, College of DuPage

How did religion frame American perception of the Late Tsarist Empire

Victoria Zhuravleva, Russian State U for the Humanities (Russia);

Religious aspect of the Soviet dissident movement in representations of the US media

Nadezhda Azhghikina, Lomonosov Moscow State U (Russia), PEN Moscow;

Mastering the American style: religious motives in the modern Russian political rhetoric

Aleksandr Okun, Samara U (Russia);

D. “'Believing in Peace and Freedom: Soviet Citizens and Foreign Friends during the Cold War"',

Roundtable Member: Alexis Peri, Boston U

Roundtable Member: David Foglesong, Rutgers, The State U of New Jersey

Roundtable Member: Christine Varga-Harris, Illinois State U

Roundtable Member: Matthias Neumann, U of East Anglia (UK)

Chair: Choi Chatterjee, California State U, Los Angeles

E. "American Belief (or not) in the Bolshevik Revolution"

Chair: Norman Saul, U of Kansas

Roundtable Member: Lee Farrow, Auburn U at Montgomery

Roundtable Member: Matt Miller, U of Northwestern-St. Paul

Roundtable Member: Lyubov Ginzburg, Independent Scholar 
Roundtable Member: William Whisenhunt, College of DuPage

F. "The New Cold War and the Magnitsky Act"

Chair: Choi Chatterjee, California State University, Los Angeles

Roundtable Member: Mitchell A. Orenstein, University of Pennsylvania

Roundtable Member: Barbara Brigitte Walker, University of Nevada, Reno

Roundtable Member: Denise J. Youngblood, University of Vermont

Roundtable Member: Victoria I. Zhuravleva, Russian State University for the Humanities 


\section{Special Issue of Russkii sbornik in honor of Bruce W. Menning}

Bruce W. Menning (Adjunct Professor of History and Russian and East European Studies, University of Kansas) reports that in the Russian tradition the publisher Modest Kolerov has devoted Russkii sbornik, no. 26 (2018), to a commemoration of Menning's $75^{\text {th }}$ birthday. Begun in 2004, Russkii sbornik can be categorized as an almanakh-style publication with a research focus on Russian history and a penchant for longer articles that often view the Russian past from an international perspective. The editorial board is fittingly international in composition, including Menning, and individual issues often bear a thematic character.

In Menning's view, no. 26 is less notable for its focus on him than for two other significant reasons. The first is Russkii sbornik's capacity to find common ground for scholarly exchange and cooperation during an especially troubled period in international relations. As eyewitness to the Cold War and as participant in several versions of academic exchanges between the United States and the Soviet Union/Russia, Menning was an early and enduring convert to the importance of persistent scholarly contact and dialog within the bilateral academic community. With Menning's same dedication to the shared academic cause and with his same devotion to the importance of Russian history, 27 scholars, balanced between 13 Russian and 14 international contributors, present the results of their research in a collection of essays organized around the unifying theme, "Russia and War." With a keen knowledge of international military historiography on Russia, member of the editorial board Oleg Airapetov bore primary responsibility for initiating the undertaking and recruiting its contributors.

This subject matter is the second factor worthy of remark. The burden of Menning's scholarship has related to two overarching themes in Russian and Soviet history: the causes and consequences of military change; and the relationship between society and the military. The thematic emphasis in Russkii sbornik, no. 26, corresponds exactly with these research interests. The very name Russkii sbornik resonates with ties to Tsarist, Soviet, and Russian military history. Although 27 scholars represent only a minor cross section of Russian national and global interest in all facets of the Russian military past, the nature of the assemblage, together with its focus and academic weight, is indicative of a disciplinary subset that is coming into its own. The irony is that - despite the volume's 13:14 Russian to non-Russian ratio - rising Russian interest now easily outstrips diminishing international interest. This shifting balance is something new, and perhaps it is the way things should be. 